\title{
Filtration process in earth fill dam body and its chemical effect on piezometers
}

\author{
Asror Yangiev, Furqat Gapparov and Dilmurod Adjimuratov* \\ Tashkent Institute of Irrigation and Agricultural Mechanization Engineers, Kary Niyoziy, 39, \\ Tashkent, Uzbekistan
}

\begin{abstract}
Estimation of aggressiveness of filtration flow in the dam body is gaining importance in providing the stability of reservoir dam and its parts. In order to estimate the aggressiveness of filtration flow in the dam body it is necessary to know the movement pattern of filtration water in reservoir dam and its effect on dam elements. The article brings up the definition of gradients of filtration flow in the dam body, analysis of the reasons of their change by cross section at the example of Tashkent reservoir dam. Besides, chemical composition of water in piezometers has been analyzed, aggressive effect of sulfate salts on piezometers, and their corrosion have been determined. Measures on systematic piezometer observations are mentioned.
\end{abstract}

\section{Introduction}

The goal of the research is to determine filtration flow gradients in the dam body, analyze the reasons of their change by cross section, estimate water filtration effect on structure elements at the example of Tashkent reservoir dam. In order to estimate the aggressiveness of filtration flow in the dam body it is necessary to know the movement pattern of filtration water in reservoir dam and its effect on the dam elements. The results of the analysis gain importance in providing the stability of reservoir dam and its parts $[1,2,3,4,5,6]$.

Filtration water in the reservoir dam body usually move in chaotic flow, in particular, filtration flow is nonpressure flow. It is known, that in nonpressure flow filtration flow has an open surface, moves towards the side from the upper part of the dam to its lower part. The head difference is

$$
\Delta \mathrm{H}=\mathrm{H}_{1}-\mathrm{H}_{2} \text {. }
$$

Filtration flow gradient $(\mathrm{J})$ is the ratio of the head difference of filtration flow in the dam body $\left(\Delta \mathrm{H}=\mathrm{H}_{1}-\mathrm{H}_{2}\right)$ to the length of filtration path:

$$
J=\frac{\Delta H}{l}
$$

Filtration flow in the dam body follow the Darcy's law. Such movement can be thoroughly observed in the base soils and in the dam body, including sands, loams and sandy loams $[7,8]$.

Filtration flow discharge in the dam body can by determined by the following equation according to the law of the French scientist Darcy:

$$
Q=K_{\phi} F \frac{\Delta H}{l}=K_{\phi} F J
$$

\footnotetext{
${ }^{*}$ Corresponding author: adjimuratov86@mail.ru
} 
where: $\mathrm{Q}$ - filtration flow discharge, i.e. amount of filtrated water through soil in a unit of time, $\mathrm{m}^{3} /$ day;

$\mathrm{K}_{\phi^{-}}$filtration coefficient, i.e. the amount, expressing the ability of the dam soil pass water through itself, $\mathrm{m} /$ day;

$\mathrm{F}$ - filtration flow zone cross section area, $\mathrm{m}^{2}$;

$l$ - filtration flow path length, $\mathrm{m}$;

$\Delta \mathrm{H}$ - head difference of the head race and the tail race, $\mathrm{m}$;

By dividing the both sides of the equation by $(F)$, we can determine filtration velocity $v=K_{\phi} J$.

Thus, by Darcy's law, it is considered that the velocity (v) of filtration or water movement in soil, composing the dam body is proportionate to filtration head gradient $(J)$ and filtration coefficient.

In cases, when head gradient $J=\frac{\Delta H}{l}=1$, the equation $v=K_{\phi} J$ becomes $v=K_{\phi}$, i.e. filtration coefficient will be equal to filtration velocity in relation with numerical value [9].

While estimating the filtration stability of the earth fill dam and its antifiltration elements the following conditions must be met:

$$
J_{\text {est }, m}=\frac{\Delta H}{t_{2}} \leq J_{c r, m}=J_{\text {доп }} \quad J_{\text {est }, m} \leq \frac{1}{\text { вn }} J_{c r}
$$

where: $J_{\text {est }, m}$ - mean gradient of the dam design element.

$1,1)$

$\gamma_{n}$ - dam reliability coefficient (I-class-1,25; II-class-1,2; III-class-1,15; IV-class-

$J_{c r}$ - mean filtration gradient allowable for earth fill dams.

\section{Method}

Collection of data from hydrometheorological stations and reservoir operation. Mathematical processing of statistical data and comparison of the obtained data with field observations $[10,11,12]$.

\section{Results}

Tashkent reservoir dam is made of local soil and has a core. Design amount of the mean filtration head gradient for the core and prism is determined by the following equation for such dams:

$$
\begin{gathered}
\text { For the core } \quad J_{\text {доп }}=\frac{1}{\text { Уn }} J_{c r} \\
\text { For the prism } \quad J_{\text {доп }}=\frac{1}{8 n} J_{c r}
\end{gathered}
$$

On the basis of field research gradients have been calculated between piezometers 1, 2, 3, 4 and 5, located at section №9 (ПК 22+00) of Tashkent reservoir dam and the results are shown in Table 1 and Picture $2[13,14]$. Tashkent reservoir dam cross section is shown in Picture 1. 


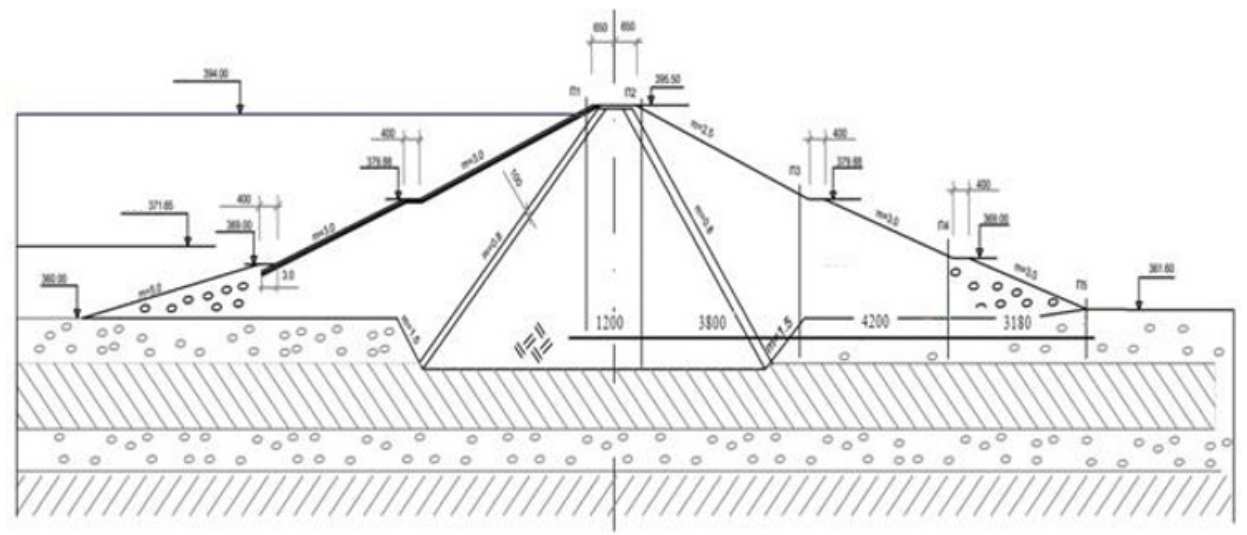

Fig. 1. Tashkent reservoir dam cross section.

Table 1. Design gradients between the piezometers in the Tashkent reservoir dam.

\begin{tabular}{|c|c|c|c|c|c|c|c|}
\hline \multirow{2}{*}{ Piezometers } & Design & \multicolumn{7}{|c|}{ Years } \\
\cline { 3 - 8 } & gradients & $\mathbf{2 0 1 2}$ & $\mathbf{2 0 1 3}$ & $\mathbf{2 0 1 4}$ & $\mathbf{2 0 1 5}$ & $\mathbf{2 0 1 6}$ & $\mathbf{2 0 1 7}$ \\
\hline П1-П2 & 0.75 & 1,33 & 0,92 & 1,17 & 1,42 & 1,16 & 1,08 \\
\hline$\Pi 2-\Pi 3$ & 0.55 & 0,42 & 0,42 & 0,42 & 0,42 & 0,39 & 0,39 \\
\hline$\Pi 3-\Pi 4$ & 0.024 & 0,017 & 0,024 & 0,018 & 0,019 & 0,024 & 0,024 \\
\hline$\Pi 4-\Pi 5$ & 0.031 & 0,031 & 0,031 & 0,029 & 0,028 & 0,031 & 0,031 \\
\hline
\end{tabular}

The analysis show, that according to the design results, filtration water movement velocity and head differences are large and filtration path is short in the section between piezometers 1,2 and 3 , but in section between piezometers 3,4 and 5 filtration water movement velocity and head differences are low and filtration path is long. As a result, in section between piezometers 3,4 and 5 head gradient sharply decreases. Water stability is observed in the piezometers, if the amount of gradient is very low $[15,16,17]$.

On the results of the research it is considered, that the movement of soil filtration is unsteady. The unsteadiness depends on the amount of gradient between piezometers, located in the dam, i.e. if the gradient is at normal level, then the change of filtration movement will comply with the pattern, and if the amount of gradient is too low, then water level stability is observed in piezometers.

Quality change analysis was conducted for the water samples, taken from Tashkent water reservoir basin and tail race drainage with the purpose of determining the state of changes mentioned above within the research and estimation of water filtration effect on the structure elements (Table 2 and pictures 3,4). 




Fig. 2. Gradient change between piezometers in section 9 (ПК 22+00) of the dam.

Table 2. Chemical analysis of the quality of water, taken from Tashkent water reservoir basin.

\begin{tabular}{|c|c|c|c|c|c|c|c|c|}
\hline \multirow{2}{*}{$\begin{array}{c}\text { Water } \\
\text { sample point }\end{array}$} & \multirow{2}{*}{ pH } & \multirow{2}{*}{$\begin{array}{c}\text { Hard } \\
\text { residual, } \\
\text { mg/l }\end{array}$} & \multicolumn{6}{|c|}{ Amount of the basic ions, dissolved in water, $\mathrm{mg} / \mathrm{l}$} \\
\hline & & & $\mathrm{HCO}_{3}^{\prime}$ & $C l^{\prime}$ & $\mathrm{SO}_{4}$ & $\mathrm{Ca}$ & $M g$ & $\begin{array}{c}\mathrm{Na}^{\prime}+ \\
\mathrm{K}^{-}\end{array}$ \\
\hline $\begin{array}{l}\text { Water } \\
\text { reservoir } \\
\text { basin }\end{array}$ & 7,4 & 265,7 & 134,4 & 15,3 & 74,6 & 48,8 & 11,2 & 20,5 \\
\hline $\begin{array}{l}\text { Drainage } \\
\text { water }\end{array}$ & 7,59 & 842,8 & 242,8 & 28,7 & 351,3 & 148 & 26 & 59 \\
\hline
\end{tabular}

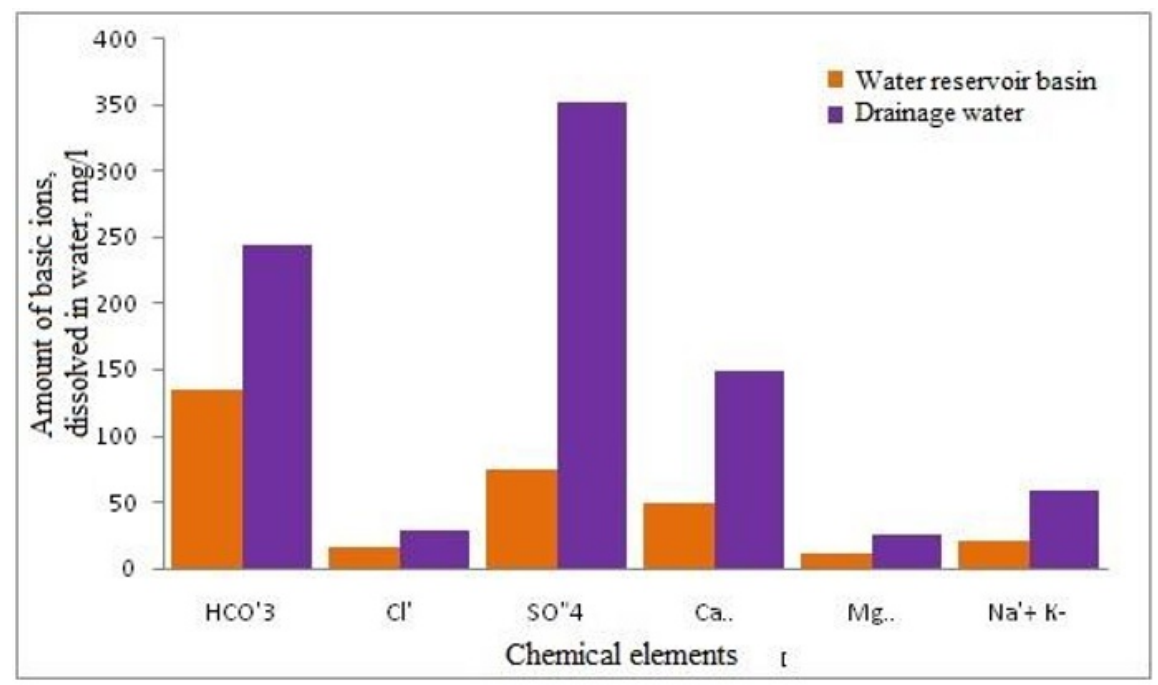

Fig. 3. Diagram of the chemical analysis of the quality of water, taken from Tashkent water reservoir basin. 

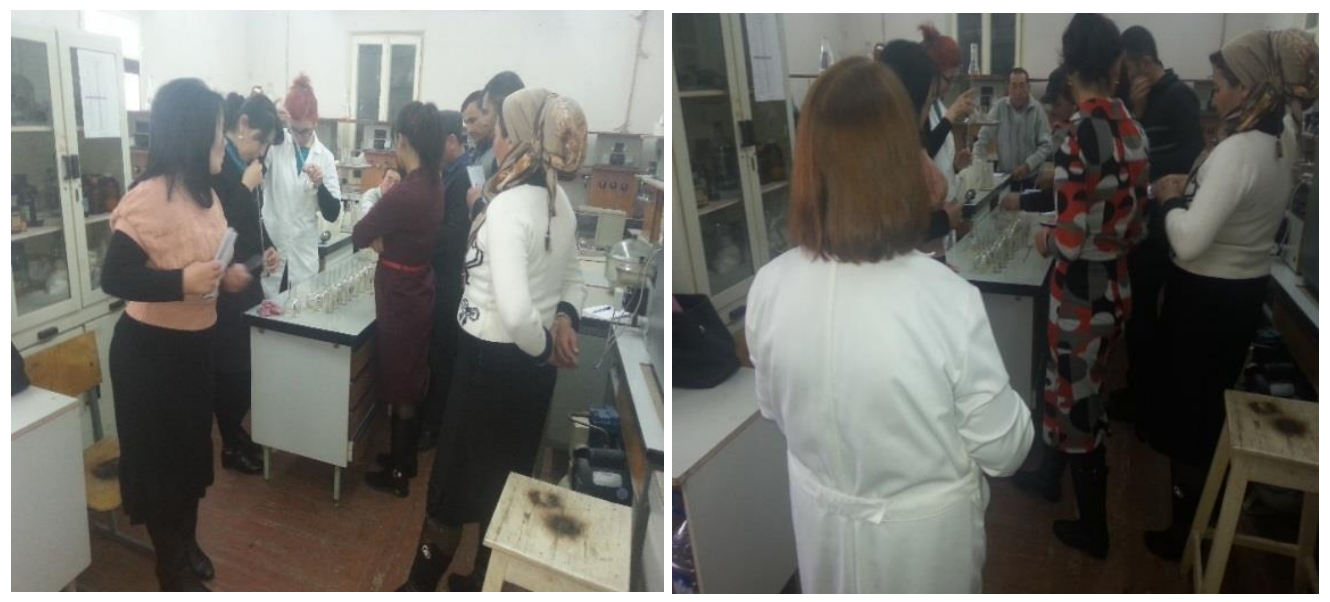

Fig. 4. The staff of the Research Institute of Irrigation and water problems are doing research in the laboratory.

In estimating the filtration water aggressiveness stability of the dam elements in the reservoir, it is necessary to consider the soil filtration coefficient. The aggressive effect of water on the elements, located in soils, where the filtration coefficient is large, can also be high. On the basis of this, water aggressiveness has also been estimated for concrete structures in the head race of Tashkent water reservoir basin (Table 3). Also the aggressiveness of water has been specified for concrete structures and piezometers, located in the body of the dam (Table 4) $[18,19,20]$.

Table 3. Water aggressiveness for concreter structures in the head race of Tashkent water reservoir basin.

\begin{tabular}{|c|c|c|c|c|c|}
\hline \multirow[b]{2}{*}{ № } & \multirow[b]{2}{*}{$\begin{array}{c}\text { Data } \\
\text { description }\end{array}$} & \multirow[b]{2}{*}{$\begin{array}{l}\text { Results of } \\
\text { laboratory } \\
\text { analysis }\end{array}$} & \multicolumn{2}{|c|}{ Nonpressure structure } & \multirow[b]{2}{*}{$\begin{array}{c}\text { Results of determining } \\
\text { aggressiveness } \\
\text { regarding concrete } \\
\text { structures }\end{array}$} \\
\hline & & & $\begin{array}{c}\text { Portland } \\
\text { cement original } \\
\text { and sulfate } \\
\text { resistant }\end{array}$ & \begin{tabular}{|c|} 
Pupallan and \\
Portland cement with \\
slag original and \\
sulfate resistant
\end{tabular} & \\
\hline 1 & 2 & 3 & 4 & 5 & 6 \\
\hline 1 & $\begin{array}{l}\text { Type of } \\
\text { structure }\end{array}$ & Nonpressure & & & \\
\hline 2 & $\begin{array}{c}\text { Size of } \\
\text { structure, } \mathrm{m}\end{array}$ & Abobe 2,5 & & & \\
\hline 3 & $\mathrm{~K}_{\phi}$, m/day & $0,1<К \phi<10$ & & & \\
\hline 4 & $\mathrm{Ca}^{2+}, \mathrm{mg} / \mathrm{l}$ & 48,8 & & & \\
\hline 5 & $\mathrm{pH}$ & 7,76 & 5,2 & 5,5 & $\begin{array}{l}\text { No aggressiveness of } \\
\text { general water acidity }\end{array}$ \\
\hline 6 & $\begin{array}{l}\mathrm{HCO}_{3}^{-}, \\
\mathrm{mg} \mathrm{eq} / 1\end{array}$ & 0,7872 & 0,4 & Not standardized & $\begin{array}{c}\text { No lye aggressiveness of } \\
\text { water }\end{array}$ \\
\hline 7 & $\begin{array}{c}\text { Carbxylic } \\
\text { acid } \mathrm{CO}_{2}, \\
\mathrm{mg} / \mathrm{l}\end{array}$ & Not determined & & & $\begin{array}{c}\text { No carboxylic acid } \\
\text { aggressiveness of water }\end{array}$ \\
\hline
\end{tabular}




\begin{tabular}{|c|c|c|c|c|c|}
\hline 8 & $\begin{array}{c}\text { Chloride, } \mathrm{Cl}^{-}, \\
\mathrm{mg}\end{array}$ & 32,9 & & & \\
\hline 9 & $\begin{array}{c}\text { Sulfate } \\
\mathrm{SO}_{4}^{2-}, \mathrm{mg} / \mathrm{l}\end{array}$ & 74,6 & $74,6<350$ & $74,6<350$ & $\begin{array}{c}\text { No sulfate aggressiveness } \\
\text { for usual cement structures }\end{array}$ \\
\hline 10 & $\mathrm{Mg}^{2+}, \mathrm{mg} / \mathrm{l}$ & 11,2 & $11,2<1000$ & $11,2<1000$ & $\begin{array}{c}\text { No magnesia } \\
\text { aggressiveness of water }\end{array}$ \\
\hline
\end{tabular}

Table 4. Aggressive effect on concrete structures and piezometers of filtration water, located in the body of Tashkent water reservoir dam.

\begin{tabular}{|c|c|c|c|c|c|}
\hline & Data & Results of & Nonpres & sure structure & Results of determining \\
\hline № & & analysis & $\begin{array}{c}\text { Portland cement } \\
\text { original and } \\
\text { sulfate resistant }\end{array}$ & $\begin{array}{c}\text { Pupallan and } \\
\text { Portland cement } \\
\text { with slag original } \\
\text { and sulfate resistant }\end{array}$ & $\begin{array}{c}\text { regarding concrete } \\
\text { structures }\end{array}$ \\
\hline 1 & 2 & 3 & 4 & 5 & 6 \\
\hline 1 & $\begin{array}{l}\text { Type of } \\
\text { structure }\end{array}$ & Nonpressure & & & \\
\hline 2 & $\begin{array}{c}\text { Size of } \\
\text { structure, } m\end{array}$ & Above 2,5 & & & \\
\hline 3 & $\mathrm{~K} \phi, \mathrm{m} / \mathrm{day}$ & $0,1<\mathrm{K} \phi<10$ & & & \\
\hline 4 & $\mathrm{Ca} 2+, \mathrm{mg} / \mathrm{l}$ & 148 & & & \\
\hline 5 & $\mathrm{pH}$ & 7,59 & 5,2 & 5,5 & $\begin{array}{c}\text { No aggressiveness of } \\
\text { general acidity of water }\end{array}$ \\
\hline 6 & $\mathrm{HCO} 3-$, & 3.98 & 0,4 & Not standardized & $\begin{array}{l}\text { No lye aggressiveness of } \\
\text { water, filtrating through } \\
\text { the water reservoir dam }\end{array}$ \\
\hline 7 & $\mathrm{mg} \mathrm{eq} / \mathrm{l}$ & Not determined & & & $\begin{array}{c}\text { No carboxylic acid } \\
\text { aggressiveness of water }\end{array}$ \\
\hline 8 & $\begin{array}{c}\text { Carbxylic } \\
\text { acid CO2, } \\
\mathrm{mg} / \mathrm{l}\end{array}$ & 28,7 & $28,7<1000$ & $28,7<1000$ & $\begin{array}{c}\text { Accelerates corrosion of } \\
\text { metal structures }\end{array}$ \\
\hline 9 & $\begin{array}{c}\text { Chloride, } \mathrm{Cl}-, \\
\mathrm{mg}\end{array}$ & 351,3 & $351,3>350$ & $351,3>350$ & $\begin{array}{c}\text { Has sulfate } \\
\text { aggressiveness for usual } \\
\text { cement and metal } \\
\text { structures } \\
\end{array}$ \\
\hline 10 & Sulfate & 26 & $26<1000$ & $26<1000$ & $\begin{array}{c}\text { No magnesia } \\
\text { aggressiveness of water }\end{array}$ \\
\hline
\end{tabular}

\section{Conclusions}

Filtration flow in the body of Tashkent water reservoir dam is sulfate aggressive with regard to concrete and metal structures, it accelerates the corrosion of piezometers in the dam. It requires taking measures on processing the concrete surfaces and joints on the head race of Tashkent water reservoir dam with hydroisolation materials and providing good operation of drainage in the tail race of the dam. Sensitivity of piezometers in the water reservoir dam must be checked, during the process of checking the sensitibility piezometers must be filled with water and then emptied, thus providing the process of water replacement in them. As a result, filtration flow water aggressiveness will decrease with regard to piezometers. 


\section{References}

1. Alekin O.A. Basics of water chemistry. Hydrometeoizdat, L.: 1970, 443 p.

2. Aravin V.I., Nosova O.N. Field research on filtration. "Energy", L.: 1969, 256 p.

3. Asarin A.E., Semenkov V.M. Design flood and dam safety // Hydraulic construction. 1992, № 8. Pp. 55-57.

4. Law of the Republic of Uzbekistan «On the safety of hydraulic structures».

5. Decree of the Cabinet of Ministers of the Republic of Uzbekistan №499 dated 16.11.2019. Regulation "On centralized inspection and evaluation of technical condition of hydraulic structures in the Republic of Uzbekistan” №03-4-245 dated 03.10.2001.

6. Muhammedov A.M. Operation of low pressure hydrosystems in rivers, transporting sediment (at the example of Central Asia). Science. Tashkent, 1976, p. 237.

7. Designer's manual. Hydraulic structures. Revised by Nedriga V.P. - M. Stroyizdat. 1983 г.

8. KMK 2.06.05-98. Earth fill dams. - T.: State committee on architecture and construction, $1998-200 \mathrm{p}$.

9. KMK 2.02.02-98. Bases of hydraulic structures. Tashkent, 1998.

10. Malik L.K., Extreme situations, related with hydraulic construction.// Hydraulic construction. 2009, № 12. Pp. 1-16.

11. Mirihulava S.E. "Reliability of hydromeliorative structures" - M, 1974.

12. Reznikov A.A., Mulikovskaya E.P., Sokolov I.Yu. Methods of analysis of natural waters. - "Nedra", 1970, P. 488.

13. Bakiev M.R., Tursunov T.N., Kaveshnikov N.T. Operation of hydraulic structures. Tashkent, 2008.

14. Goldberg V.M. Relationship between underground water pollution and natural environment. Gidrometeoizdat, L.: 1987, 248 p.

15. KMK 2.06.08-97 Hydraulic structures. Concrete and reinforced concrete structures. State architecture and construction committee of the Republic of Uzbekistan. Tashkent, 1998.

16. KMK 0.07.02-97 Hydraulic transport structures in rivers and water reservoirs. Tashkent, 1996.

17. KMK 2.06.04-97. Loads and impacts on hydraulic structures (through waves, ice and ships). Tashkent, 1998.

18. Evaluation of water quality with regard to concrete is conducted according to standards and technical conditions: № 114-54 «Hydraulic concrete. Indications and standards of aggressiveness of water - medium for reinforced concrete structures».

19. CH 249-63 «Indications and standards of aggressiveness of water - medium for reinforced concrete structures». http:// www.meganorm.ru.

20. Corrosive activity is evaluated by $\mathrm{CH} 266-63$ «Regulations for protecting underground metal structures from corrosioin». 